\title{
Protecting global health security through the International Health Regulations: requirements and challenges
}

\author{
Kumanan Wilson MD MSc, Barbara von Tigerstrom LLB PhD, Christopher McDougall MA
}

$\infty \quad$ See related editorial by Attaran, page 9

Published at www.cmaj.ca on June 12, 2008.

$\mathrm{T}$ he International Health Regulations, the principle document governing the response to public health emergencies that pose an international threat, were revised in 2005 and became binding international law on June 15, 2007. ${ }^{1}$ These new regulations, unanimously approved by the World Health Assembly, differ in important ways from previous versions (Table 1) and represent a major step forward in protecting global public health security. ${ }^{2.3}$ Despite their importance, countries will face several challenges to implementing the regulations. Many developing countries lack the capacity to detect and respond to public health emergencies, and developed countries may choose to act unilaterally. Decentralized states such as Canada will also face specific challenges to implementation. In May 2008, the Auditor General of Canada issued a report highlighting areas in which Canada has had difficulty complying with the new regulations. ${ }^{4}$

In this article, we describe how the regulations provide new guidance to member states on preparing for and responding to public health emergencies, some of the challenges to compliance with the regulations, and Canada's role in helping to ensure their successful implementation.

\section{Features of the revised regulations}

The goal of the revised International Health Regulations are to protect against the international spread of epidemics and other public health emergencies without unnecessary interference with international travel and trade. To achieve this objective, the regulations provide new guidance to member states on several matters (Figure 1). The fundamental premise of the regulations is that preparation and early detection and response are essential to protect against global health emergencies. The regulations therefore require member states to assess their core capacity for effective public health surveillance and response within 2 years and meet requirements for core capacity within the subsequent 3 years. ${ }^{5}$

Ensuring that public health emergencies are reported in a timely manner to the World Health Organization (WHO) is a priority of the new regulations. The previous version of the regulations covered only 3 specific diseases: plague, cholera and yellow fever (Table 1). ${ }^{6}$ The revised regulations instead introduce the concept of a "public health emergency of international

\section{Key points}

- The revised International Health Regulations are designed to protect against the international spread of public health emergencies without unnecessary interference with international travel and trade.

- The regulations require member states to develop national surveillance and response systems.

- The regulations describe how international health emergencies are to be identified, reported and managed.

- The implementation of the regulations faces several challenges, including lack of capacity in developing countries, the risk of independent action in developed countries and poor coordination between federal and regional governments in decentralized countries.

- Canada can lead the way by demonstrating its compliance with the regulations and by championing their implementation in developing countries.

concern." To assist countries in determining what events should be reported, the new regulations provide a mechanism to evaluate whether events are potential international threats. ${ }^{3.7}$ Member states are required, within 48 hours, to assess any event occurring within their territory and to determine whether it may be a public health emergency using an algorithm (see Appendix 1, available online at www.cmaj.ca/cgi/content/full/179/1 /44/DC1). ${ }^{8}$ An outbreak of certain diseases, such as SARS (severe acute respiratory syndrome), will always be considered a potential public health emergency of international concern.

Recognizing the importance of a rapid response, the new regulations require that member states report potential public health emergencies to WHO within 24 hours after they have identified and assessed them. Member states must also designate a "National Focal Point" for communication with WHO. Unlike in the previous regulations, initial notification of WHO can be made on a confidential basis. The new regulations also allow WHO to consider unofficial "reports from sources other

From the Ottawa Health Research Institute and Department of Medicine (Wilson), University of Ottawa, Ottawa, Ont.; the University of Saskatchewan College of Law (von Tigerstrom), Saskatoon, Sask.; and the Department of Health Policy, Management and Evaluation (McDougall), University of Toronto, Toronto, Ont. 
than notifications or consultations." This means that, if government officials in a member state delay reporting a potential public health emergency, WHO can use information from unofficial sources that may be available by email or the Internet, for example, to assess the situation. WHO will consult with the member state concerned and attempt to obtain verification before taking any action; however, it can share the information with other member states, and even directly with the public in some situations. These alternatives for gathering information are important, because the regulations do not describe penalties for member states that fail to report, or for that matter fail to comply with the regulations in other respects.

In addition to protecting public health, another important goal of the regulations is to prevent unnecessary economic harm. In the event of a possible health emergency, countries may be anxious to close their borders to protect their populations. Premature or unjustified closing of borders, however, can have serious negative economic consequences. During outbreaks of cholera in the 1990s in Peru and eastern Africa, other countries banned imports of fish and other food products from the affected areas and restricted the entry of travellers from Peru, despite clear advice from WHO that there was no justification for such measures. Peru estimated trade losses for the year of the outbreak at over US\$770 million. ${ }^{910}$ In 1994 India was hit with extensive restrictions on travel and trade during a localized outbreak of plague, again contrary to WHO advice; the estimated cost to India's economy was more than US\$2 billion. ${ }^{9}$

To limit economic damages from public health emergencies effectively, a multifaceted approach is necessary. ${ }^{11}$ The new regulations attempt to prevent unnecessary interference with international travel and trade by making WHO the primary arbiter on decisions related to controlling public health

Table 1: Major differences between the new International Health Regulations and previous versions*

\begin{tabular}{ll}
\hline Previous regulations & \multicolumn{1}{c}{ New regulations } \\
\hline $\begin{array}{l}\text { Focus was on } 3 \text { diseases } \\
\text { (cholera, plague, yellow } \\
\text { fever) }\end{array}$ & $\begin{array}{l}\text { Focus is on all "public health } \\
\text { emergencies of international } \\
\text { concern" } \dagger\end{array}$ \\
\hline $\begin{array}{l}\text { Regulations defined } \\
\text { measures that member } \\
\text { states could take }\end{array}$ & $\begin{array}{l}\text { The World Health Organization } \\
\text { (WHO) makes recommendations } \\
\text { on measures that can be taken; } \\
\text { member states can exceed the } \\
\text { recommended measures if they } \\
\text { comply with the conditions }\end{array}$ \\
\hline $\begin{array}{l}\text { Limited surveillance and } \\
\text { response obligations }\end{array}$ & $\begin{array}{l}\text { More extensive surveillance and } \\
\text { response obligations }\end{array}$ \\
\hline $\begin{array}{l}\text { Mandatory reporting of } \\
\text { cases and automatic } \\
\text { sharing of information } \\
\text { with other member states }\end{array}$ & $\begin{array}{l}\text { Mandatory reporting of } \\
\text { potential public health } \\
\text { emergencies of international } \\
\text { concern; WHO may use and } \\
\text { share information from } \\
\text { unofficial sources }\end{array}$ \\
\hline
\end{tabular}

*The previous regulations were issued in 1969 and updated in 1981. The new regulations were revised in 2005 and came into force in June 2007. tEvents that (a) may constitute a public health risk to other member states through the international spread of disease and/or (b) may require a coordinated international response. threats. Once WHO has received information about an event, the Director-General of WHO is responsible for determining, on the advice of an expert committee, whether the event constitutes a "public health emergency of international concern" and, if so, what temporary recommendations will be issued to guide member states in their control efforts. Recommendations must take into consideration the views of the affected country, scientific principles and evidence, the least intrusive measures that would provide protection, and relevant international agreements. Examples of temporary recommendations include requiring medical examinations or vaccinations, quarantine or isolation of individuals or goods, or denial of entry. Member states are not limited to these recommendations. However, if they put in place measures that exceed those recommended, they must comply with a set of conditions.

\section{Challenges to compliance}

The revised International Health Regulations have been criticized for subordinating health concerns to security and economic concerns. ${ }^{12}$ They have also been described as overemphasizing surveillance, ${ }^{13}$ not placing enough emphasis on assistance for developing countries ${ }^{13}$ and lacking a legal mechanism to ensure compliance. ${ }^{14}$

Despite these criticisms, the new regulations were unanimously approved by the WHO member states. All member states are bound by their requirements unless they specifically objected to them by the end of 2007. ${ }^{15}$ As of February 2008, no member states had rejected the regulations, 188 had designated National Focal Points, 76 had already conducted an assessment of their national core capacities, and 50 had nominated individuals to the International Health Regulations Roster of Experts. ${ }^{16}$ A number of countries, including Australia, Syria, Finland, Sweden, Columbia, France, Georgia and Germany, have already recognized the regulations as domestic law or have incorporated elements of the agreement into their national health legislation. ${ }^{17}$ A number of other countries, including Argentina, Spain, Brazil, South Africa and the European Community, have passed administrative regulations that cite the new International Health Regulations. Still other countries, including the United Kingdom, ${ }^{18}$ are considering "all-hazards" approaches to the reform of their public health legislation.

In spite of these efforts and the recognition of the importance of the regulations, several factors may prevent full national compliance. This is particularly true when compliance may leave countries, or regions within countries, vulnerable.

\section{Limited capacity in developing countries}

Developed countries have a considerable interest in the regulations succeeding. Many developed countries will likely be geographically removed from areas in which public health emergencies, such as an influenza pandemic, may develop. It is in their interest that countries in high-risk regions comply with the regulations, to provide an early warning so that the developed countries can take appropriate measures to protect their populations. ${ }^{12}$

For many developing countries, however, early detection and reporting of a public health emergency may be of little 
benefit if the country lacks the capacity to control the outbreak in its early stages. Early reporting could also trigger rapid closing of international borders to travel and trade, which could be devastating to their economies. Furthermore, investment in surveillance infrastructure, as required by the regulations, may divert scarce resources away from areas of public health that have a greater need, such as the treatment and control of tuberculosis, malaria and HIV/AIDS. ${ }^{12,19}$

Noncompliance by less developed countries will reduce the likelihood of controlling public health emergencies. A warning that the concerns of less developed countries may undermine the new regulations has emerged with current efforts to plan for an influenza pandemic. Historically, countries have shared information and virus samples through the Global Influenza Surveillance Network for monitoring and vaccine development. However, the expected transfers of biological data may result in a country losing financial benefits that could be derived from the development and sale of a vaccine developed from the data. Also, there are no guarantees that a country will be provided with an adequate amount of the vaccine to administer to its population. The insecurity in current arrangements was partly responsible for Indonesia's recent decision to withhold virus samples from WHO and instead consider entering into an exclusive agreement with Baxter Pharmaceuticals. In exchange for Indonesian avian influenza viral isolates, the company would guarantee Indonesia access to any resulting vaccine. ${ }^{20}$ In an effort to persuade Indonesia to resume its participation in the Global Influenza Surveillance Network, WHO has been working on arrangements to ensure access to vaccines for developing countries. ${ }^{21}$ Some issues relating to the implementation of these arrangements remain unresolved, but Indonesia is reported to have sent virus samples to WHO in February 2008, albeit for risk assessment (surveillance) purposes only and not for vaccine development. ${ }^{22,23}$

\section{Unilateral actions by developed countries}

Given the lack of incentives and limited capacity for developing countries to comply with the new regulations, developed countries may decide to undertake their own measures to protect their population. Such measures could include bilateral agreements between wealthy nations and countries that are most likely to be affected by emerging public health threats. In the United States, the proposed Global Pathogen Surveillance Act would make the provision of financial assistance to poorer countries to develop the capacity to detect and respond to public health threats conditional on permitting investigation of outbreaks by the US Centers for Disease Control and Prevention and WHO and on the transfer of pathogen surveillance data. ${ }^{24,25}$ The US Department of Defence Global Emerging Infections Surveillance and Response System is a network of overseas centres that conducts global infectious diseases surveillance. ${ }^{26}$ These approaches, in and of themselves, are not necessarily detrimental to international health strategies, particularly if the wealthy countries involve and closely interact with key international organizations, as the United States has with WHO. In fact, such approaches may be viewed as a reasonable solution for poorer countries that need financial support for their public health infrastructure and for wealthy countries that need the in- formation provided by the infrastructure in which they invest. Nevertheless, such strategies open the door to countries taking actions based on self-interest alone, where in essence surveillance information and biological data are purchased and not necessarily shared with international community.

\section{Implementing the regulations in federal states}

The new regulations, which set minimum standards for surveillance and reporting, require that countries adapt their governance strategies to meet these standards. However, the power to implement the new regulations may not exist at the national level in certain decentralized countries. For example, public health surveillance falls under the constitutional jurisdiction of

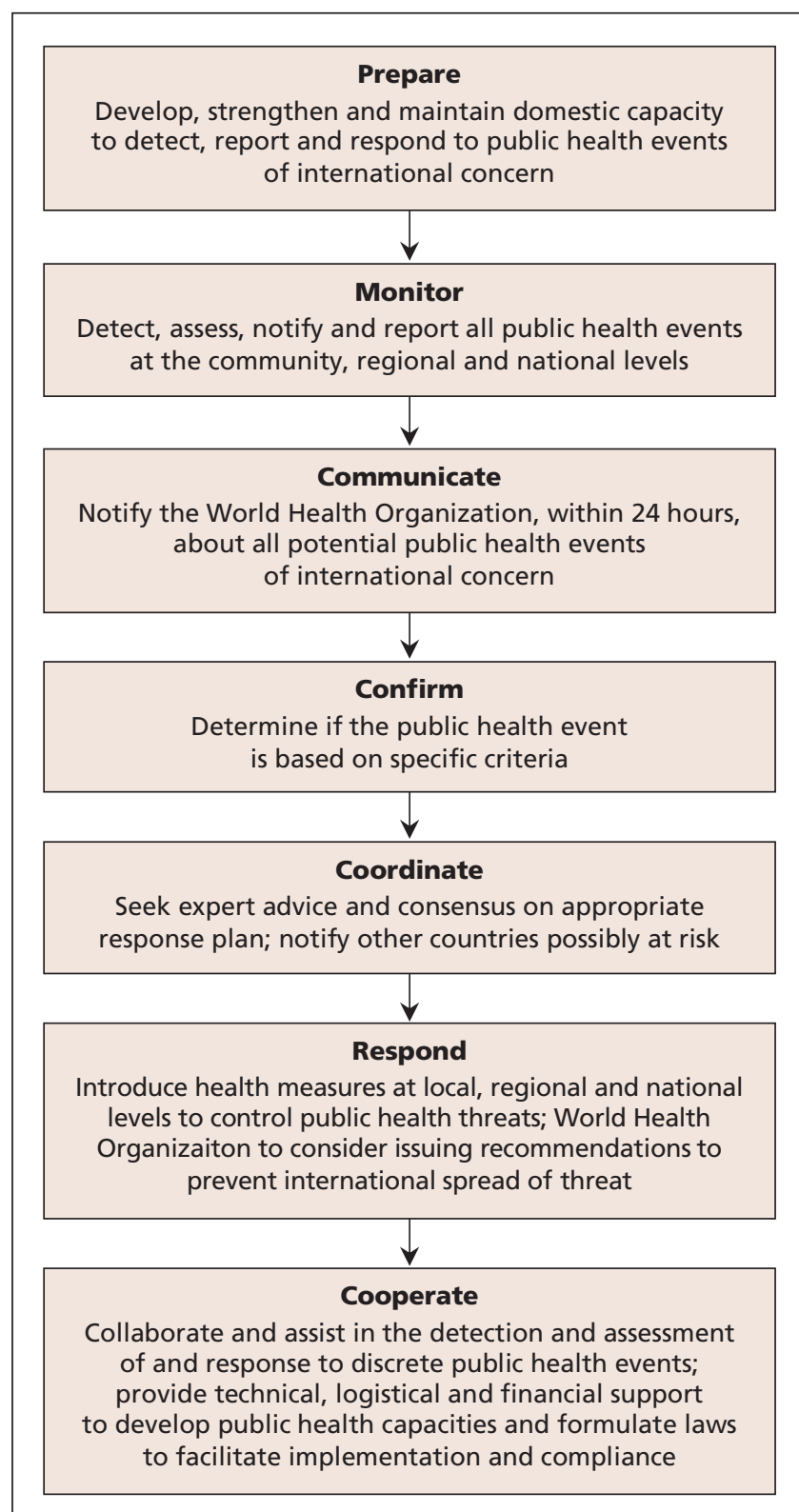

Figure 1: A summary of the key steps outlined in the revised International Health Regulations to prepare for and respond to public health emergencies of international concern. ${ }^{1}$ 
the regional governments in many federal states. The federal government may not have the legislative authority to require surveillance that meets the standards of the regulations. Similarly, it may not have the legislative authority to require regional governments to share information on potential public health emergencies. Also, regional governments may be reluctant to voluntarily share this information if it could put local economies at risk. ${ }^{27,28}$ The problems that decentralization poses to timely and effective national responses to public health emergencies was evident in both China and Canada during the SARS. ${ }^{29}$

\section{What is Canada's role?}

Canada has an opportunity to provide leadership in this new global approach to emerging public health threats. It's first responsibility, however, is to become compliant with the revised regulations.

Canada's ability to comply should not be taken for granted. Developing the necessary core capacity and the surveillance and reporting systems will not be easy. ${ }^{30}$ The outbreak of SARS revealed the lack of capacity and appropriate systems, and the consequences of such gaps. ${ }^{31}$ In particular, the surveillance systems were not effective, and there were no information-sharing protocols. The consequences included the failure to notify WHO in a timely manner and the introduction of a potentially avoidable travel advisory. ${ }^{32,33}$ When an affected nursing attendant travelled to the Philippines, Canada's lack of capacity put other nations with weaker health infrastructures at risk.

Canada's failure to develop cohesive surveillance and reporting systems has been examined in 3 reports of the Auditor General of Canada. ${ }^{4,34,35}$ The most recent report, issued in May 2008, identified difficulties this country will have in adhering to the revised International Health Regulations. ${ }^{4}$ An inability to comply places Canadians at risk and sends a signal to less developed countries that the regulations are not a priority.

Canada has taken some important steps to comply with the regulations, such as designating a National Focal Point and passing new quarantine legislation. ${ }^{36}$ However, as identified by the Auditor General, 2 key obstacles remain: the absence of an integrated national surveillance system, and the lack of mechanisms to ensure timely domestic reporting to allow the National Focal Point to meet its international notification requirements ${ }^{4}$ (Box 1). This country's efforts to develop surveillance systems have been plagued by intergovernmental disputes. ${ }^{34,37}$ Despite the innovation Canada demonstrated in developing the Global Public Health Intelligence Network WHO's early-warning system - it has not succeeded in developing an integrated national surveillance system. This is primarily because such a system must have compatible features and data-sharing privileges. Achieving provincial agreement on these matters remains an obstacle.

Even in the presence of an effective surveillance system, there must be a guarantee that information would flow from local to regional authorities and ultimately to the National Focal Point for reporting to WHO within the prescribed timelines. There is no legislation or comprehensive set of formal agreements compelling such transfers. So far, the federal govern- ment has attempted to achieve this collaboratively without the use of legislation or conditional funding arrangements. ${ }^{37}$ Other federal countries have chosen different paths. Australia has passed new health security legislation that provides a framework for sharing of relevant data between the states and territories and the federal government. ${ }^{38}$ The United States has passed legislation in which development of surveillance systems and transfer of data to federal levels is tied to ongoing funding. ${ }^{39}$

Canada's other responsibility is to assist less developed countries in complying with the new regulations. Through the development of the Global Public Health Intelligence Network, Canada has already made an invaluable contribution to international health surveillance ${ }^{40}$ Canada's ability to develop effective national surveillance information systems and share this technology with developing countries will add to our contribu-

Box 1: Actions Canada should take to facilitate the successful implementation of the International Health Regulations

Create an integrated national surveillance system

- Obstacle: Development of surveillance system that allows sharing of data between regions.

- Possible solutions: Federal conditional funding for provincial surveillance systems that meet specific requirements for data standardization and sharing. Federal guidelines, regulations or legislation that require provincial surveillance systems to meet national standards.

- Auditor General's recommendation: "[T]he Public Health Agency of Canada should ensure that its internal systems for managing information about significant public health events are comprehensive and well-documented." ${ }^{4}$

Ensure timely domestic reporting and international notification

- Obstacle: Ensuring that information on potential public health emergencies of international concern is transferred to the National Focal Point to allow for timely reporting to the World Health Organization

- Possible solutions: Development of a comprehensive set of intergovernmental agreements making transfer of relevant information to the National Focal Point mandatory. Regulations or legislation requiring such transfer of information to be available if intergovernmental agreements are not agreed upon.

- Auditor General's recommendation: "[T]he Public Health Agency of Canada should work with its partners to establish an action plan with clear and realistic deadlines for implementing the memorandum of understanding on the sharing of information during a public health emergency."

Help developing countries build their capacity and infrastructure for surveillance and response

- Obstacle: Developing countries may not have the capacity or incentives to put surveillance and response systems in place that meet the requirements of the new regulations.

- Possible solutions: Canada could share surveillance technology with developing countries. It could contribute to the development of response and compensation systems that would provide assistance to developing countries that meet the reporting requirements of the new regulations. 
tions in this area. Providing assistance and contributing toward the development of stockpiles of antiviral drugs and vaccines that can be used by developing countries may also alleviate their anxiety about the equity of the reciprocal relationships into which they have entered and thereby encourage the sharing of viral isolates. ${ }^{22}$ Similarly, developing a compensation plan for countries whose economy might be subsequently harmed by the early reporting of public health emergencies could further promote early reporting.

\section{Conclusion}

Public health officials have recognized the importance of collective action to manage international health emergencies. If countries fail to act, or act independently, it will result in a less than optimal response that will increase the harms to their citizens and disrupt the global economy. Compliance with the revised International Health Regulations is a critical step toward preventing this from happening. Canada, a key advocate for the regulations, should lead the way both by demonstrating its own compliance with the regulations and by championing their implementation in all countries.

\section{This article has been peer reviewed.}

Competing interests: Kumanan Wilson was a paid consultant to the 2008 report on health surveillance by the Auditor General of Canada and received funding from the Public Health Agency of Canada. No competing interests declared for Barbara von Tigerstrom or Christopher McDougall.

Contributors: All of the authors contributed to the conception, drafting and final approval of the paper.

Acknowledgements: This manuscript is based in part on information emerging from a workshop examining implementation of the International Health Regulations in decentralized states (www.ihrfederalism.com). This workshop was supported by grants from the Canadian Institutes of Health Research, the Public Health Agency of Canada, the Canadian International Development Agency and the International Development Research Centre. We acknowledge the contributions of all of those who participated in this workshop.

Kumanan Wilson is the recipient of the Canada Research Chair in Public Health Policy.

\section{REFERENCES}

1. Fifty-eighth World Health Assembly resolution WHA58.3: Revision of the International Health Regulations. Geneva: World Health Organization; 2005. Available: www.who.int/gb/ebwha/pdf_files/WHA58/A58_4-en.pdf (accessed 2008 May 26).

2. A new public health world order. Lancet Infect Dis 2004;4:475.

3. Baker MG, Fidler DP. Global public health surveillance under new international health regulations. Emerg Infect Dis 2006;12:1058-65.

4. Chapter 5: Surveillance of infectious diseases - Public Health Agency of Canada In: 2008 May report of the Auditor General of Canada. Ottawa: Office of the Auditor General of Canada; May 2008. Available: www.oag-bvg.gc.ca/internet/English /aud_ch_oag_200805_05_e_30701.html (accessed 2008 May 26).

5. Core capacity requirements [Annex 1]. In: Fifty-eighth World Health Assembly resolution WHA58.3: Revision of the International Health Regulations. Geneva: World Health Organization; 2005. Available: www.who.int/gb/ebwha/pdf_files/WHA58 /A58_4-en.pdf (accessed 2008 June 5).

6. World Health Organization. International health regulations (1969) 3rd ed. Geneva: The Organization; 1983.

7. Fidler DP. From international sanitary conventions to global health security: the new international health regulations. Chin J Int Law 2005;4:1-68.

8. Decision instrument for the assessment and notification of events that may constitute a public health emergency of international concern [Annex 2]. In: Fifty-eighth World Health Assembly resolution WHA58.3: Revision of the International Health Regulations. Geneva: World Health Organization; 2005. p. 45. Available: www.who .int/gb/ebwha/pdf_files/WHA58/A58_4-en.pdf (accessed 2008 June 5).

9. Cash RA, Narasimhan V. Impediments to global surveillance of infectious dis- eases: consequences of open reporting in a global economy. Bull World Health Organ 2000;78:1358-67.

10. Aginam O. International law and communicable diseases. Bull World Health Organ 2002;80:946-51.

11. Von Tigerstrom B. The revised International Health Regulations and restraint of national health measures. Health Law J 2005;13:35-76.

12. Calain P. Exploring the international arena of global public health surveillance. Health Policy Plan 2007;22:2-12.

13. Public-health preparedness requires more than surveillance. Lancet 2004;364:1639-40.

14. Sturtevant JL, Anema A, Brownstein JS. The new International Health Regulations: considerations for global public health surveillance. Disaster Med Public Health Prep 2007;1:117-21.

15. Constitution of the World Health Organization, 22 July 1946, 14 UN Treaty Series 185 , article 22 .

16. World Health Organization. Implementation of the International Health Regulations (2005): report by the Secretariat. 2008. Available: www.who.int/csr/A61_7 -en.pdf (accessed 2008 May 21).

17. World health Organization. WHO - International Digest of Health Legislation. Available: www.who.int/idhl-rils/frame.cfm?language=english (accessed 2008 May 21).

18. UK Department of Health. Review of parts II, V and VI of the Public Health (Control of Disease) Act 1984: a consultation on proposals for changes to public health law in England. London (UK): UK Department of Health; 2007. p. 7-8. Available: www.dh .gov.uk/en/Consultations/Closedconsultations/DH_073452 (accessed 2008 June 5).

19. Calain P. From the field side of the binoculars: a different view on global public health surveillance. Health Policy Plan 2007;22:13-20.

20. Fidler DP. Influenza virus samples, international law, and global health diplomacy. Emerg Infect Dis 2008;14:88-94.

21. Pandemic influenza preparedness: sharing of influenza viruses and access to vaccines and other benefits [resolution WHA60.28]. Adopted at the 60th World Health Assembly; Geneva; 23 May 2007. Available: www.who.int/gb/ebwha /pdf_files/WHA60/A60_R28-en.pdf (accessed 2008 May 28).

22. Garrett L, Fidler DP. Sharing H5N1 viruses to stop a global influenza pandemic. PLoS Med 2007;4:e330.

23. Liem MV. Indonesia resumes sharing bird flu samples. Jakarta: Reuters; $2008 \mathrm{Feb}$ 22. Available: http://uk.reuters.com/article/latestCrisis/idUKJAK19930820080222 (accessed 2008 May 21)

24. Mitka M. Global pathogen surveillance. JAMA 2006;295:617.

25. Global Pathogen Surveillance Act of 2007, S. 1687 [110th].

26. Culpepper R, Kelley P. DoD-Global Emerging Infections Surveillance and Response System. Navy Med 2002;93:10-4.

27. Wilson K, McDougall C, Upshur R. The new International Health Regulations and the federalism dilemma. PLoS Med 2006;3:e1.

28. Wilson K, McDougall C, Fidler DP, et al. Strategies for implementing the new International Health Regulations in federal states. Bull WHO 2008;3:215-20.

29. Alphonso C, York G. Canadian health officials rapped by WHO. Globe and Mail [Toronto] 2003 June 13;A1,A6.

30. McDougall C, Wilson K. Canada's obligations to global public health security under the revised International Health Regulations. Health Law Rev 2007;16:25-32.

31. National Advisory Committee on SARS and Public Health. Learning from SARS: renewal of public health in Canada - executive summary. Ottawa: Public Health Agency of Canada; 2003. Available: www.phac-aspc.gc.ca/publicat/sars-sras /naylor/exec-eng.php (accessed 2008 May 21).

32. Campbell A. Problem 7: poor coordination with federal government. In: The SARS Commission interim report. SARS and public health in Ontario. Toronto: Government of Ontario; 2004. p. 65-72. Available: www.sarscommission.ca/report/Interim_Report.pdf (accessed 2008 May 21).

33. Svoboda T, Henry B, Shulman L, et al. Public health measures to control the spread of the severe acute respiratory syndrome during the outbreak in Toronto. N Engl J Med 2004;350:2352-61.

34. Chapter 14: National health surveillance: diseases and injuries. In: 1999 September report of the Auditor General of Canada. Ottawa: Office of the Auditor General of Canada; Sept 1999. Available: www.oag-bvg.gc.ca/internet/English/aud_ch_oag _199909_14_e_10143.html (accessed 2008 May 26).

35. Chapter 2: Health Canada — national health surveillance. In: 2002 September status report of the Auditor General of Canada. Ottawa: Office of the Auditor General of Canada; Sept 2002. Available: www.oag-bvg.gc.ca/internet/English/aud_ch _oag_200209_2_e_12387.html (accessed 2008 May 26).

36. Quarantine Act, RSC 2005, c20, s82. Repeals RSC 1985, cQ-1.

37. Wilson K, McCrea-Logie J, Lazar H. Understanding the impact of intergovernmental relations on public health: lessons form reform initiatives in the blood system and health surveillance. Can Public Policy 2004:30:177-94.

38. Parliament of the Commonwealth of Australia. National Health Security Act 2007 (No. 174, 2007)

39. Pandemic and All-Hazards Preparedness Act, Pub L No. 109-417, 101 et seq (2006).

40. Mykhalovskiy E, Weir L. The Global Public Health Intelligence Network and early warning outbreak detection: a Canadian contribution to global public health. Can J Public Health 2006;97:42-4.

Correspondence to: Dr. Kumanan Wilson, The Ottawa HospitalCivic Campus, Administrative Services Building, Rm. 1009, Box 684, 1053 Carling Ave., Ottawa ON K1Y 4E9; fax 613 761-5492;

kwilson@ohri.ca 